\title{
A tribute to Professor Yong Zhao
}

\author{
Zheng Tan ${ }^{1}$, Jun Tang ${ }^{2}$, Feng Wang ${ }^{3}$, Xiaocui $\mathrm{Li}^{4}$, Yanlian Chen ${ }^{4}$, Zhou Songyang ${ }^{4 \bowtie}$ \\ ${ }^{1}$ Institute of Zoology, Chinese Academy of Sciences (CAS), Beijing 100101, China \\ 2 Xiamen Multi-Dimension Biomedical Technology Co., Ltd, Xiamen 361000, China \\ ${ }^{3}$ School of Basic Medical Sciences, Tianjin Medical University, Tianjin 300203, China \\ 4 School of Life Sciences, Sun Yat-sen University, Guangzhou 510275, China \\ $\bowtie$ Correspondence: songyanz@mail.sysu.edu.cn (Z. Songyang) \\ Accepted August 31, 2021
}

Professor Yong Zhao was the Dean of School of Life Sciences at Sun Yat-sen University and a renowned biologist whose studies focused on the role of telomeres and telomerase in cancer and aging. Dr. Zhao's postdoctoral mentor Professor Woodring E. Wright (1949-2019) of University of Texas Southwestern Medical Center (UTSW) once remarked, "It will be hard for anyone else in my lab to match up to the superb performance of Yong Zhao."

Yong was born on June 25th, 1976, in Dangyang, Hubei Province. He obtained his bachelor's degree in Biochemistry from Nankai University in 1998 and his Doctor of Philosophy degree in Biophysics from College of Life Sciences at Wuhan University in 2003. For his doctoral thesis work under the guidance of Professor Zheng Tan (Fig. 1), Yong developed a method that enabled simultaneous and quantitative measurements of multiple kinetic parameters during nucleic acid duplex formation using an optical biosensor based on surface plasmon resonance. When applied to the study of human telomere G-quadruplexes, it revealed the dynamic structure of human telomeres and helped expand the application of optical biosensors (Zhao et al., 2004).

After completing his postdoctoral research in analytical chemistry at the College of Chemistry and Molecular Sciences in Wuhan University in 2006, Yong continued his postdoctoral training in cell biology under the tutelage of Professors Woodring E. Wright and Jerry W. Shay at UTSW (Fig. 2), where his ingenuity, creativity, and tenacity shone again. For example, he developed new ways to quantify the length of telomeric overhangs (Zhao et al., 2008), and monitor the processes of telomeric G-strand extension and C-strand fill-in (Zhao et al., 2009). Using these innovative methods, Yong provided concrete evidence that had led to the revision of the telomere elongation model to a stepwise process where G-strand extension during the $S$ phase is followed by $\mathrm{C}$-strand fill-in during the late $S / G_{2}$ phase. This outstanding discovery, published as a Feature Article in the leading science journal Cell (Zhao et al., 2009), also provides additional targets for the development of anti-cancer therapeutics. In 2009, Yong joined the UTSW faculty as an Assistant Lecturer, where his research has helped refine the understanding of telomerase-dependent elongation of telomeres. For example, his work revealed the dichotomy in telomerase action in which multiple telomerase molecules can act on each telomere end under non-equilibrium conditions as opposed to a single telomerase molecule at each telomere end under steady-state conditions. These results were published as the cover story in the journal Molecular Cell (Zhao et al., 2011).

In the summer of 2011, Yong returned to China and devoted his life to scientific research in his homeland. He was appointed as 100 Top Talents Professor in the School of Life Sciences at Sun Yat-sen University and established the Laboratory of Cell Aging and Cancer Research in Guangzhou (Fig. 3). It was here that he led his students to the discovery that telomeric double-strand breaks (DSBs) can be efficiently repaired by homologous recombination in proliferating but not stress-induced or replicative senescent cells, contrary to the then widely held belief that telomeric DSBs could not be repaired in cells and would thus trigger cell senescence (Mao et al., 2016). Professor Zhao's group also found p53 and AKT to be key factors in suppressing spontaneous apoptosis in ALT cells, which points to the inhibition of p53 and AKT as a new therapeutic approach that specifically targets ALT cancers ( $\mathrm{Ge}$ et al., 2019). With the unprecedented spread of the novel coronavirus SARS-CoV2 since the end of 2019, COVID-19 has quickly become a global health issue. Yong and his team were able to identify the small molecule $\mathrm{C} 1632$ as an inhibitor that could block SARS-CoV-2 replication and viral-induced inflammation by upregulating the let-7 gene (Xie et al., 2021). This exciting work underlines $\mathrm{C} 1632$ as a potential therapeutic candidate in treating COVID-19. 
Figure 1. The doctoral graduation thesis defense of Yong in Wuhan.

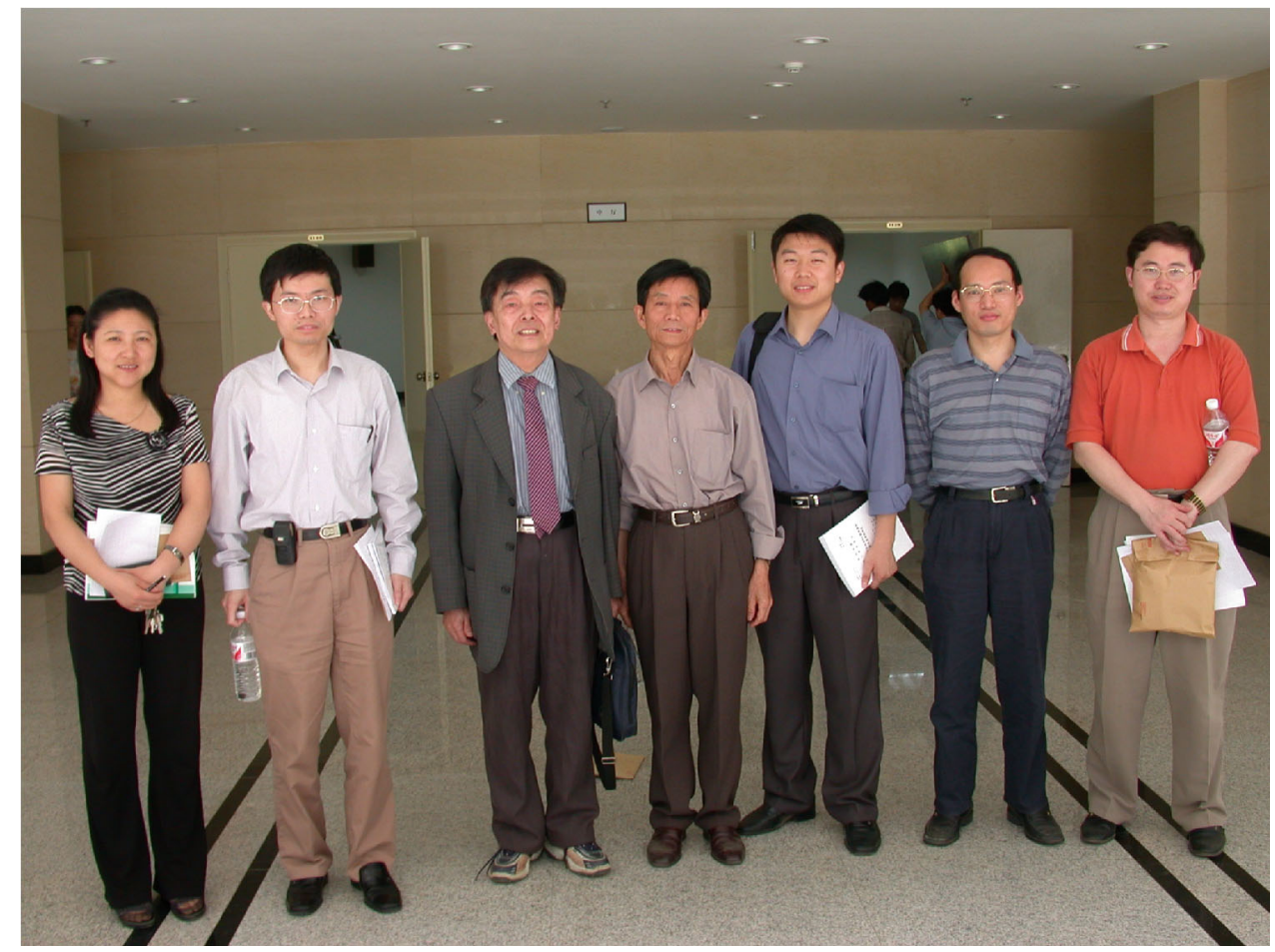

Figure 2. Professor Woodring E. Wright and Yong in USA.

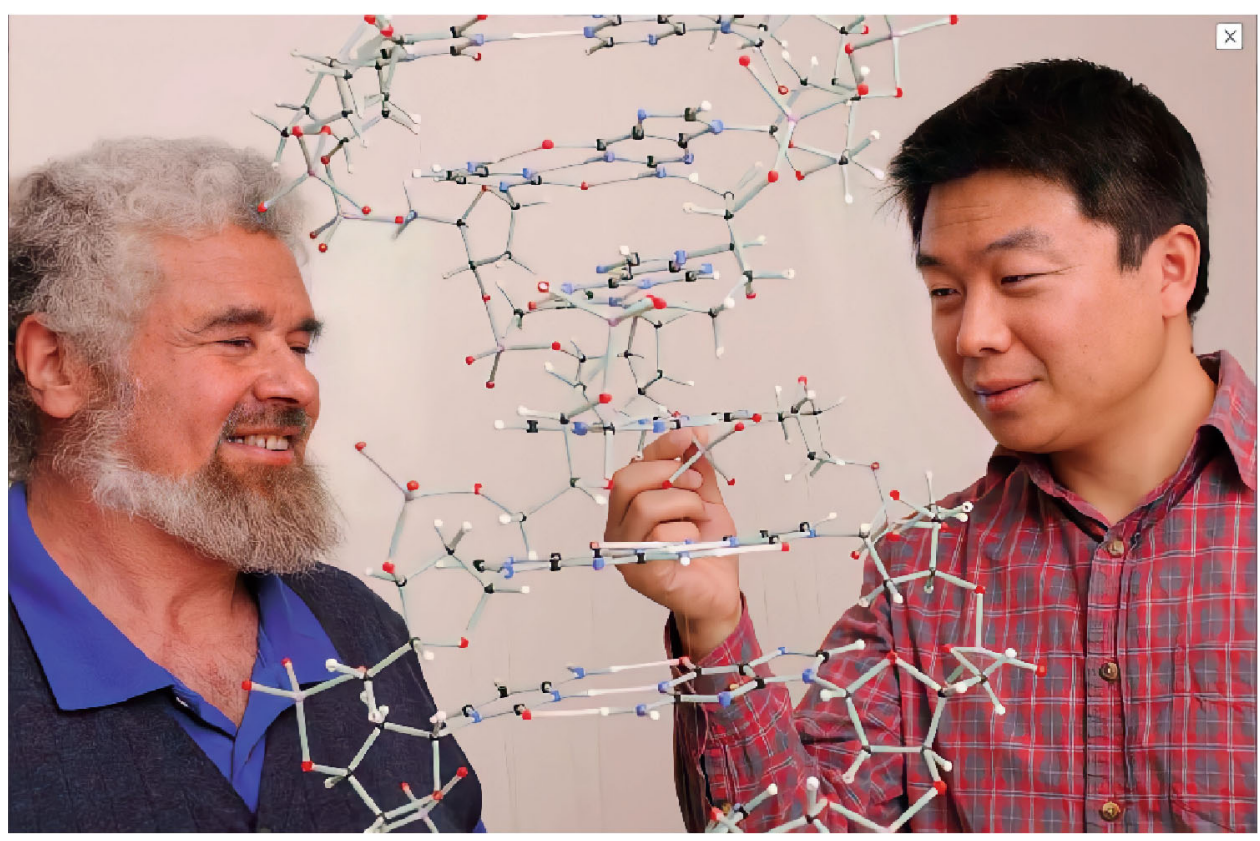

Professor Yong Zhao garnered national and international attention for his work in the cancer and aging fields, with over 40 published articles and book chapters as well as 6 patents in the areas of telomere analysis and anti-cancer therapies. For his outstanding work and achievements, Yong received many honors. He was awarded postdoctoral fellowships by the American Federation for Aging Research and the Ellison Medical Foundation. And he was the key member in the Innovative Scientific Research Team of Guangdong
Province to develop targeted anticancer drugs and vaccines. Yong won the Excellent Young Scientists Fund in 2013 and was named a Pearl River Scholar of Guangdong Province in the same year. His significant contributions earned him the National Science Fund for Distinguished Young Scholars in 2020.

Yong was above all a consummate educator. Serving as Party Secretary (2018) and then Dean (2020) of the School of Life Sciences, he wholeheartedly devoted his time and 
Figure 3. Yong and his doctoral students in Guangzhou.

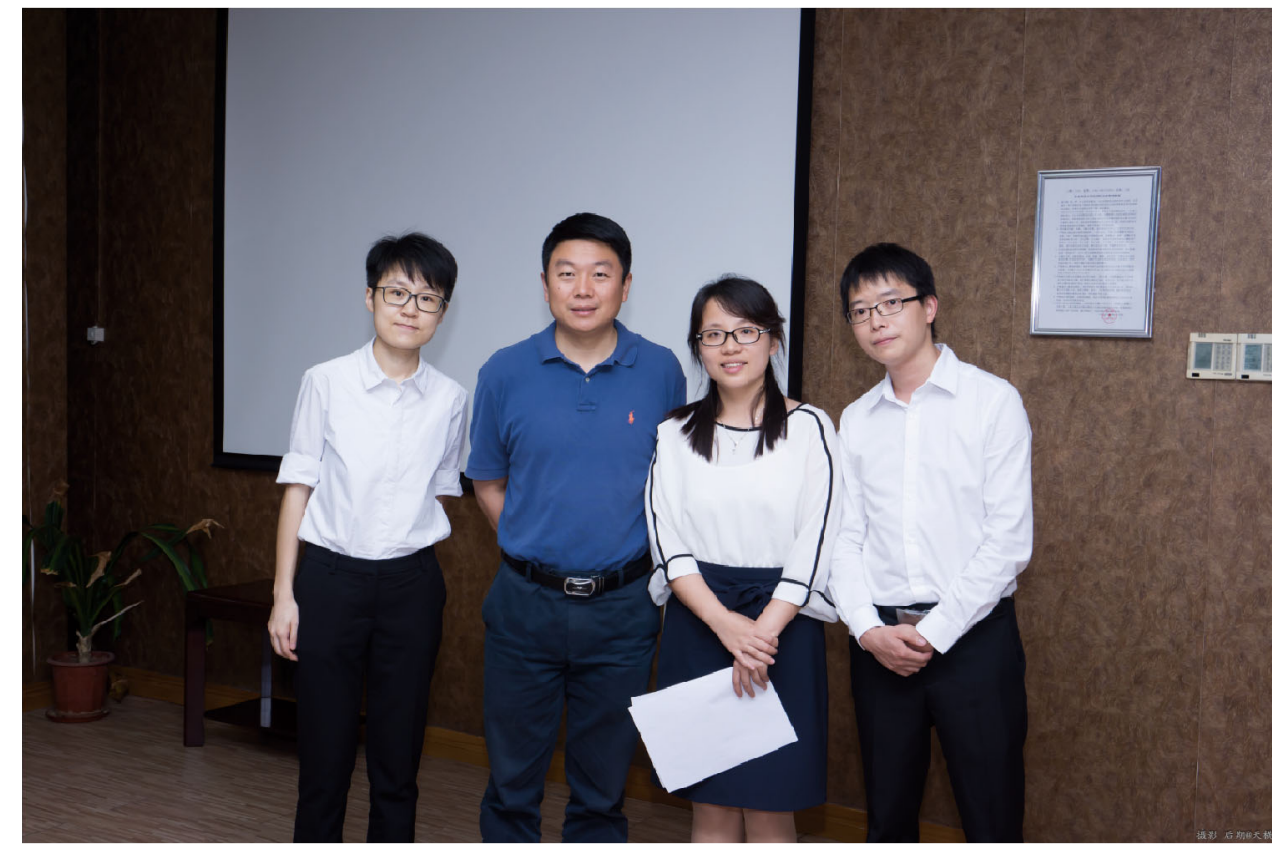

energy to improving the quality of teaching and motivating student learning. He was particularly generous with his time for students, often meeting with them face to face to provide support and encouragement. Unfailingly kind and dedicated, Yong went far beyond merely teaching techniques and knowledge, he was committed to fostering collaborative spirits and critical thinking skills in all the students.

The sudden and unexpected passing of Professor Yong Zhao at the age of 45 on April 8th, 2021 has left a huge void. A compassionate patriot, a distinguished scientist, an advocate for science and education, a skillful leader of the School of Life Sciences, a respected and big-hearted colleague, and an inspiring and beloved teacher, Yong had touched so many lives in so many ways. He will be dearly missed and forever present in the hearts and memories of everyone lucky enough to have known him.

\section{OPEN ACCESS}

This article is licensed under a Creative Commons Attribution 4.0 International License, which permits use, sharing, adaptation, distribution and reproduction in any medium or format, as long as you give appropriate credit to the original author(s) and the source, provide a link to the Creative Commons licence, and indicate if changes were made. The images or other third party material in this article are included in the article's Creative Commons licence, unless indicated otherwise in a credit line to the material. If material is not included in the article's Creative Commons licence and your intended use is not permitted by statutory regulation or exceeds the permitted use, you will need to obtain permission directly from the copyright holder. To view a copy of this licence, visit http:// creativecommons.org/licenses/by/4.0/.

\section{REFERENCES}

Ge Y, Wu S, Zhang Z, Li X, Li F, Yan S, Liu H, Huang J, Zhao Y (2019) Inhibition of p53 and/or AKT as a new therapeutic approach specifically targeting ALT cancers. Protein Cell 10:808-824

Mao P, Liu J, Zhang Z, Zhang H, Liu H, Gao S, Rong YS, Zhao Y (2016) Homologous recombination-dependent repair of telomeric DSBs in proliferating human cells. Nat Commun 7:12154

Xie C, Chen Y, Luo D, Zhuang Z, Jin H, Zhou H, Li X, Lin H, Zheng X, Zhang $J$ et al (2021) Therapeutic potential of C1632 by inhibition of SARS-CoV-2 replication and viral-induced inflammation through upregulating let-7. Signal Transduct Target Ther 6:84

Zhao Y, Kan ZY, Zeng ZX, Hao YH, Chen H, Tan Z (2004) Determining the folding and unfolding rate constants of nucleic acids by biosensor. Application to telomere G-quadruplex. J Am Chem Soc 126:13255-13264

Zhao Y, Hoshiyama H, Shay JW, Wright WE (2008) Quantitative telomeric overhang determination using a double-strand specific nuclease. Nucleic Acids Res 36:e14

Zhao Y, Sfeir AJ, Zou Y, Buseman CM, Chow TT, Shay JW, Wright WE (2009) Telomere extension occurs at most chromosome ends and is uncoupled from fill-in in human cancer cells. Cell 138:463-475

Zhao Y, Abreu E, Kim J, Stadler G, Eskiocak U, Terns MP, Terns RM, Shay JW, Wright WE (2011) Processive and distributive extension of human telomeres by telomerase under homeostatic and nonequilibrium conditions. Mol Cell 42:297-307 